\title{
Simple trachelectomy of early invasive cervix carcinoma in the second trimester
}

\author{
Ikinci trimesterde, erken invaziv serviks karsinomanin basit trakelektomisi
}

\author{
Radek Chvatal ${ }^{1}$, Peter Oppelt ${ }^{1}$, Christian Koehler ${ }^{2}$, Alvin Habelsberger ${ }^{1}$, Cemil Yaman ${ }^{1}$ \\ 'Department of Gynecology, General Hospital of Linz, Linz, Austria \\ 2Department of Gynecology, Charité University Hospital Berlin, Berlin, Germany
}

\section{Abstract}

Although cervical carcinoma is among the most frequently encountered malignancies during pregnancy only a small number of cases during pregnancy have been reported. Usually, the patients have been treated by radical trachelectomy with or without chemotherapy during the pregnancy.

Laparoscopic pelvic lymph node dissection with frozen section, simple trachelectomy and cerclage were performed in the $22^{\text {nd }}$ week of pregnancy. The histologic examination confirmed a squamous cell carcinoma of the cervix of $35 \mathrm{~mm}$ diameter, lymphangioinvasion (L1), low grade, clear surgical margin, negative pelvic lymph nodes according to stage Figo IB. Adjuvant chemotherapy with three cycles of cisplatin was performed after surgery. Delivery was performed by cesarean section followed by radical hysterectomy in the the $32^{\text {nd }}$ week of pregnancy. Recurrent adjuvant chemotherapy with three cycles of cisplatin and local vaginal iridium radiation were performed after surgery. Patient had no surgery related complications. No relapse of cancer has been diagnosed during the following 16 months.

Simple trachelectomy may be alternative treatment option to radical trachelectomy for pregnant women with early stage cervical cancer without lymph node metastasis.

(J Turkish-German Gynecol Assoc 2011; 12: 121-3)

Key words: Cervical cancer, pregnancy, trachelectomy, chemotherapy Received: 20 July, 2010

Accepted: 24 August, 2010

\section{Özet}

Servikal karsinoma gebelik süresince en sık karşılaşılan maligniteler arasında olmasına rağmen gebelik süresince olguların sadece küçük bir kısmı rapor edilmektedir. Genellikle, hastalar gebelik sırasında kemoterapi ile birlikte ya da kemoterapi olmaksızın radikal trakelektomi ile tedavi edilmektedir.

Donmuş kesit (frozen section) ile laparoskopik pelvik lenf nodu diseksiyonu, basit trakelektomi ve serklaj gebeliğin 22. haftasında gerçekleştirildi. Histolojik inceleme; lenfanjiyoinvazyon (L1), düşük derece, temiz cerrahi sinır, negatif pelvik lenf nodları ile FiGO IB evresine uyan, $35 \mathrm{~mm}$ çapında serviksin yassı hücreli karsinomunu doğruladı. Cerrahiden sonra üç döngü sisplatin ile adjuvan kemoterapi uygulandı. Doğum gebeliğin 32. haftasında sezaryen ile ve takibinde radikal histerektomi ile gerçekleştirildi. Cerrahiden sonra üç döngü sisplatin ile yinelenen adjuvan kemoterapi ve lokal vajinal iridyum ışınlaması yapıldı. Hastada cerrahi ile ilişkili komplikasyonlar olmadı. İzleyen 16 ay süresince kanser tekrarı tanısı konmadı.

Basit trakelektomi lenf nodu metastazı olmayan erken evre serviks kanserli gebe kadınlar için radikal trakelektomiye alternatif tedavi seçeneği olabilir.

(J Turkish-German Gynecol Assoc 2011; 12: 121-3)

Anahtar kelimeler: Servikal kanser, gebelik, trakelektomi, kemoterapi

Geliş Tarihi: 20 Temmuz 2010

Kabul Tarihi: 24 Ağustos 2010

\section{Introduction}

Cervical cancer is the most common gynecologic malignancy associated with pregnancy. Approximately $15 \%$ of all cervical cancers and $45 \%$ of surgically treated stage IB cancers occur in woman under the age of 40 (1).

Radical hysterectomy terminates the pregnancy and results in the loss of future fertility. Abdominal or vaginal radical trachelectomy is a fertility-preserving alternative to radical hysterectomy for young women with cervical cancer (2-9). However, there is no evidence that a radical trachelectomy is required for all early invasive cancers (10).

This case report presents the treatment of a pregnant patient in the second trimester, with squamous carcinoma of the cervix Figo IB, by simple trachelectomy. A brief review of the literature is also presented.

\section{Case Report}

High grade lesion was diagnosed in the 20nd week of pregnancy by routine check of the cervix. The biopsy revealed invasive cervical cancer. The clinical examination revealed Figo Ib stage disease.

Fetal malformations were ruled out by sonography. Laparoscopic pelvic lymph node dissection (Fig. 1 a,b,c,d) with frozen section, simple trachelectomy and cerclage were performed in the 22 nd week of pregnancy. The histologic examination confirmed a squamous cell carcinoma of the cervix with a $35 \mathrm{~mm}$ transverse diameter, $17 \mathrm{~mm}$ depth, lymphangioinvasion (L1), low grade, clear surgical margin, negative pelvic lymph nodes $(7+8)$ pT1b1 G3 N0.

Adjuvant chemotherapy with three cycles of cisplatin was performed after surgery. 

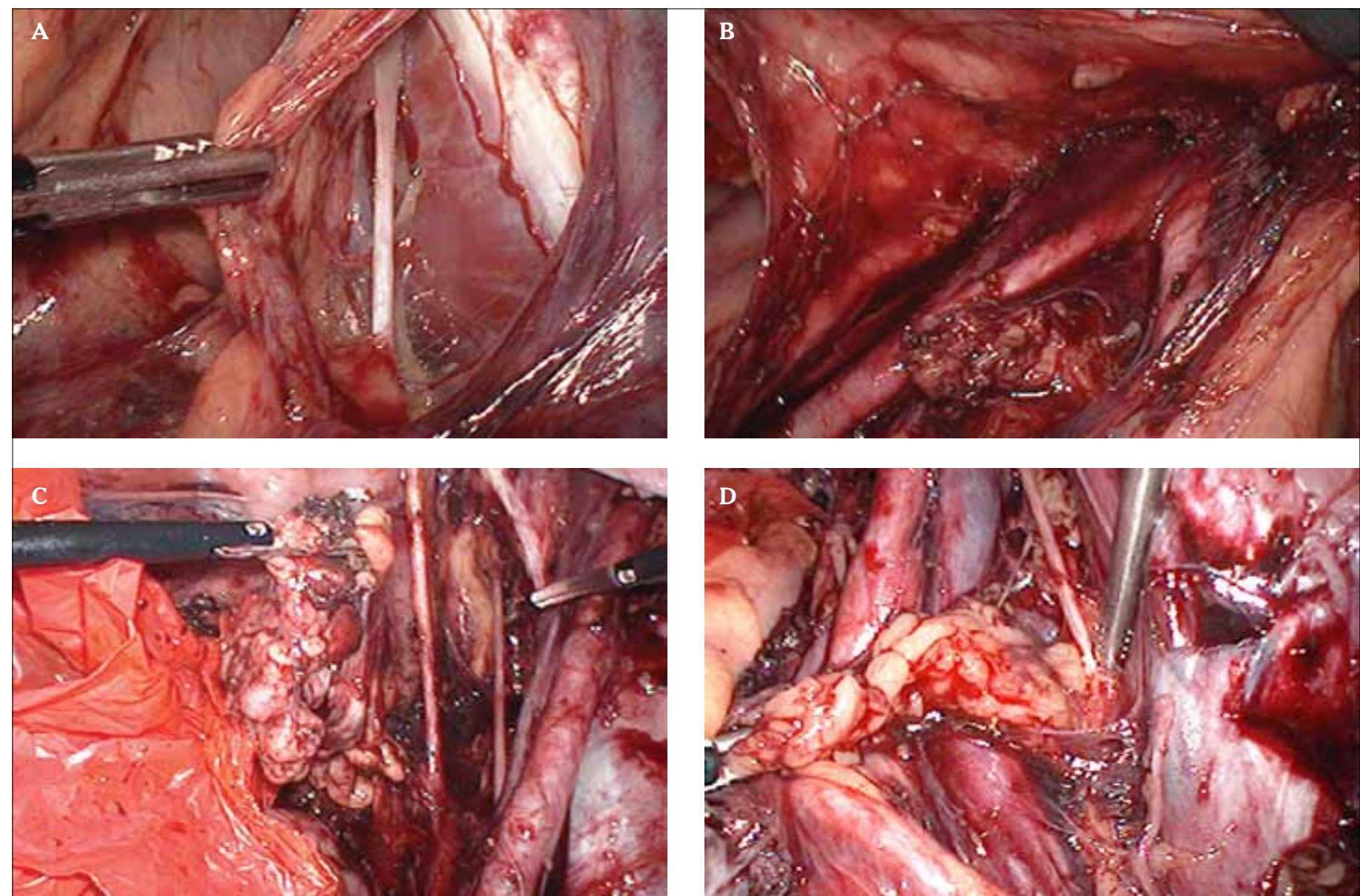

Figure 1. A) Lymphonodectomy in regio lumbosacralis, B) N. obturatorius, C) "en bloc" resection of lymph nodes in regio obturatoria, D) Lymphonodectomy in regio presacralis

Monthly examinations showed no sign of fetal or maternal complications. Because of the cortisone therapy given along with the cisplatin,lung priming was not necessary. A longitudinal laparotomy has been chosen as an approach for the C-section with following piver III hysterectomy, paraaortal, presacral lymphadenectomy and ovarian transposition. All eleven sampled lymph nodes were not infiltrated by cancer cells. The final staging was Figo I b, pT1b1,N0 (0/26), M0, G3, L1. Recurrent adjuvant chemotherapy with three cycles of cisplatin and local vaginal iridiumradiation were performed after surgery.

The newborn developed normally and showed no chemotherapically related side effects. Apgar score was 8/9/9. Post partum, a persistent ductus arteriosus with slight enlargement of the left ventricle, which was closed by conservative treatment, was diagnosed. Post partum, the patient underwent further three cycles of radio-chemotherapy. No cancer reccurence was diagnosed for the following 16 months.

\section{Discussion}

Management of cervical cancer during pregnancy depends on several factors, such as stage of the disease, nodal status, histological subtype of the tumor, term of the pregnancy, and whether the patient wishes to continue her pregnancy. However, the review of the literature showed that, in patients with early-stage disease diagnosed during the first two trimesters of pregnancy, there is an increasing tendency to delay pregnancy in order to achieve fetal lung maturity.

The largest data on fertility-sparing procedures in early stage cervical cancer has been reported with radical trachelectomy in non pregnant women (2-6). Characteristic of this method, which was first described by Dargent et al. (2), is the removal of parametrium inferior to the upper vagina. To avoid pregnancy termination by radical hysterectomy, radical trachelectomy is also used in pregnant women with early cervical cancer $(7,8)$. However, there is no evidence that a radical trachelectomy is required for all early invasive cancers (9). The question is whether less aggressive surgery provides similar effectiveness to radical trachelectomy. Rob et al. (10) determined the feasibility and safety of using less-radical fertility-preserving surgery in non-pregnant women in a comparative study, and suggested that large cone or simple trachelectomy combined with laparoscopic pelvic lymphadenectomy can be a feasible method that yields a high, successful pregnancy rate.

Laparoscopic lymph node dissection seems to be a safe procedure in pregnancy (11-13).

To evaluate the feasibility, toxicity, and pharmacokinetics in the maternal and fetal compartments during chemotherapy 
in pregnancy patients with cervical cancer, Marnitz et al. (13) examined cisplatin levels in the amniotic fluid and umbilical cord. Amniocentesis was performed at the time of the second cisplatin cycle. They found that the concentration in the amniotic fluid samples reached $10 \%$ of the maternal blood levels. At the time of delivery, the corresponding concentration in the amniotic fluid was approximately one-third of the umbilical cord levels. However, teratogenic effects of cisplatin used in the second and third trimester of pregnancy are not described (14-17).

When the clinical stage of the disease has been determined, the family and oncologists have to make the decision either to terminate the pregnancy or perform surgery. The presence of nodal metastasis is the most important predictive factor, and its assessment is crucial in deciding whether the pregnancy can safely continue. The poor prognosis for patients with lymph node metastasis should be taken into consideration.

Treatment of stage IB cervical cancer in pregnancy by simple trachelectomy, cerclage, and laparoscopic pelvic lymph node dissection with following neoadjuvant chemotherapy as a first step therapy may improve fetal and maternal short-terrm outcome in second trimester pregnancy. Continued research in this area will determine the long term outcome of the young women.

\section{Conflict of interest}

No conflict of interest was declared by the authors.

\section{References}

1. Covens A, Rosen B, Murphy J, Laframboise S, DePetrillo AD, Lickrish $\mathrm{G}$, et al. Changes in the demographics and perioperative care of stage IA(2)/IB(1) cervical cancer over the past 16 years. Gynecol Oncol 2001; 81: 133-7. [CrossRef]

2. Dargent D, Martin X, Sacchetoni A, Mathevet P. Laparoscopic vaginal radical trachelectomy: a treatment to preserve the fertility of cervical carcinoma patients. Cancer 2000; 88: 1877-82. [CrossRef]

3. Hertel H, Köhler C, Grund D, Hillemanns P, Possover M, Michels W, et al. Radical vaginal trachelectomy (RVT) combined with laparoscopic pelvic lymphadenectomy: prospective multicenter study of 100 patients with early cervical cancer. Gynecol Oncol 2006; 103: 506-11. [CrossRef]

4. Nishio H, Fujii T, Kameyama K, Susumu N, Nakamura M, Iwata T, Aoki D. Ab-dominal radical trachelectomy as a fertility-sparing procedure in women with early-stage cervical cancer in a series of 61 women. Gynecol Oncol 2009; 115: 51-5. [CrossRef]
5. Kim JH, Park JY, Kim DY, Kim YM, Kim YT, Nam JH. Fertility-sparing laparos-copic radical trachelectomy for young women with early stage cervical cancer. BJOG 2010; 117: 340-7.

6. Ramirez PT, Schmeler KM, Malpica A, Soliman PT.Safety and feasibility of robotic radical trachelectomy in patients with earlystage cervical cancer. Gynecol Oncol 2010; 116: 512-5. [CrossRef]

7. Mandic A, Novakovic P, Nincic D, Zivaljevic M, Rajovic J. Radical abdominal trachelectomy in the 19th gestation week in patients with early invasive cervical carcinoma: case study and overview of literature. Gynecol Oncol 2010; 116: 151-2.

8. Abu-Rustum NR, Tal MN, DeLair D, Shih K, Sonoda Y.Radical abdominal trachelectomy for stage IB1 cervical cancer at 15-week gestation. Gynecol Oncol 2010;116:151-2.

9. Gien LT, Covens A. Fertility-sparing options for early stage cervical cancer. Gynecol Oncol 2010; 117: 350-7. [CrossRef]

10. Rob L, Pluta M, Strnad P, Hrehorcak M, Chmel R, Skapa P, Robova $\mathrm{H}$. A less radical treatment option to the fertility-sparing radical trachelectomy in patients with stage I cervical cancer. Gynecol Oncol 2008; 111: S116-20. [CrossRef]

11. Alouini S, Rida K, Mathevet P. Cervical cancer complicating pregnancy: impli-cations of laparoscopic lymphadenectomy. Gynecol Oncol 2008; 108: 472-7. [CrossRef]

12. Favero G, Lanowska M, Schneider A, Marnitz S, Köhler C. Laparoscopic pel-vic lymphadenectomy in a patient with cervical cancer stage Ib1 complicated by a twin pregnancy. J Minim Invasive Gynecol 2010; 17: 118-20. [CrossRef]

13. Marnitz S, Schmittel A, Bolbrinker J, Schmidt FP, Fons G, Kalache K, et al. The therapeutic management of a twin pregnancy complicated by the presence of cervical cancer, following laparoscopic staging and chemotherapy, with an emphasis on cisplatin concentrations in the fetomaternal compartments amnion fluid, umbilical cord, and maternal serum. Fertil Steril 2009; 92: 1748. [CrossRef]

14. Caluwaerts S, VAN Calsteren K, Mertens L, Lagae L, Moerman P, Hanssens $\mathrm{M}$, et al. Neoadjuvant chemotherapy followed by radical hysterectomy for invasive cervical cancer diagnosed during pregnancy: report of a case and review of the literature. Int $\mathrm{J}$ Gynecol Cancer 2006; 16: 905-8. [CrossRef]

15. Boyd A, Cowie V, Gourley C. The use of cisplatin to treat advancedstage cer-vical cancer during pregnancy allows fetal developement and prevents cancer progression: report of case and review of the literature. Int. J Gynecol Cancer 2009; 19: 273-6. [CrossRef]

16. Tewari K, Cappucini F, Gambino A, Kohler MF, Pecorelli S, DiSala PJ. Neoadjuvant chemotherapy in the treatment of locally advanced cervical carcinoma in pregnancy: a report of two cases and review of issues specific to the management of cervical carcinoma in pregnancy including planned delay of therapy. Cancer 1998; 82: 1529-34. [CrossRef]

17. Bader AA, Petru E, Winter R. Long-term follow-up after neoadjuvant che-motherapy for high-risk cervical cancer during pregnancy. Gynecol Oncol 2007; 105: 269-72. [CrossRef] 